International Research Journal of Management, IT \& Social Sciences
Available online at https://sloap.org/journals/index.php/irjmis/
Vol. 7 No. 1, January 2020, pages: 197-204
ISSN: 2395-7492
https://doi.org/10.21744/irjmis.v7n1.840

\title{
Changes in Uses of Salutations in British English
}

Ahdi Hassan a

Rod Mitchell ${ }^{\mathrm{b}}$

Hakim Ali Buriro ${ }^{c}$

\section{Article history:}

Submitted: 18 November 2019

Revised: 27 December 2019

Accepted: 12 January 2020

\section{Keywords:}

academic;

English language;

language change;

pragmatics;

salutations;

\begin{abstract}
As is only natural, British English has undergone a change in its use of salutations. An important question is whether there has been significant influence from immigrants and/or other varieties of English on how British salutations are used, and, if so, how this is realised. We approach the analysis by evaluating how salutations have evolved and are evolving in appropriateness in spoken and written contexts. A finding from the data is that polite salutations appear to be becoming more generalized, i.e. more neutral. This paper draws on data from contemporary English in social, academic and YouTube texts, in both in formal and informal spoken and written contexts, as well as from the last few decades, exploring social, cultural and pragmatic meanings of salutations, with attention given to academic, social and stylistic uses such as when addressing strangers or the humorously ironic.
\end{abstract}

International research journal of management, IT and social sciences (C) 2020. This is an open access article under the CC BY-NC-ND license (https://creativecommons.org/licenses/by-nc-nd/4.0/).

\section{Corresponding author:}

Ahdi Hassan,

IATELS, International Association for Technology,

Education and Language Studies, Istanbul, Turkey.

Email address: ahdihassan441@gmail.com

\footnotetext{
IATELS, International Association for Technology, Education and Language Studies, Istanbul, Turkey

b Timor Leste with Linguarama Milan / ENI Timor Leste / ENI ECU Milan, Italy

c Allama Iqbal Open University, Islamabad, Pakistan
} 


\section{Introduction}

Salutations, or Address Forms, those "words speakers use to designate the person. They are talking to while they are talking to them" (Fasold, 2000), express acknowledgement of the other in discourse and set (or reestablish) the social relationship between the interlocutors. Salutations are also open to negotiation, particularly at the first meeting, as the interlocutors juggle to establish their social relationship. Having strong culture-semantic content, salutations are found in all cultures, and like all other cultural aspects, differ to varying degrees from culture to culture, not only from language to language, but even within the one language, from community to community, and also change over time. The "good morrow" common in English around 150 years ago has disappeared, to be replaced by "good morning". The evolution in salutations in Britain reflect the fact that British culture is undergoing some change, as is only natural, given that culture evolves with society.

This paper summarizes the norms of Salutations in the language, giving an overview of use in helping us to understand mono-cultural and cross-cultural communication in and through English in Britain, as well as giving an overview to ESOL teachers and students of the cultural settings of British salutations, leading to mutual understanding. Cross-cultural communication has always been a reality, through trade, travel, language learning, war, the spread of religion and art forms, colonization and empire building, international study, intermarriages, pen-pals, and so on. However, the recent developments in technology, in particular the internet, and ease of travel have vastly increased intercultural encounters, both from afar and face-to-face (Abercrombie, 1979). In only a matter of hours, a plane can take us anywhere in the world, and with the intensification of the global market place, today's world-wide intercultural contacts are far more common than at any other period of the history of the world.

Confucius categorized society into five types of relationships, husband to wife, parent to child, elder to younger brother (or more generally elders to youngsters), Ruler to Minister or subject, and friend to friend. He advocated social unity all over the world so that society can be harmonious as a collective society. This philosophy entailed the use of kinship address forms across all five categories, such as when a child refers to his father's friend or neighbour or even a male stranger, he addresses that person as "uncle" or "grandpa", depending on relative age. Such use of address forms is not easy to come to terms with by peoples from other cultures, where kin terms are normally only used for kin. On the other hand, as the same system exists in non-Confucian societies, ranging from Animistic-Totemic societies through Buddhism, Hinduism, and into local Islamic and Christian societies, Confucius had merely codified a preexisting system common to all Sino-Tibetan peoples and beyond (Baugh \& Cable, 1991).

\section{Literature review}

Greetings, compliments, orders, showing modesty as opposed to brashness. There are many cultural and personal traits that have linguistic expression. Ways of complimenting others, of expressing modesty, of 'selling oneself' (e.g., how one presents oneself in a job interview as opposed to boasting) are quite different from language culture to language culture, and region to region. When English speakers are praised, they smile, often self-consciously, and thank the person who paid the compliment, unless the compliment was unwanted. Among tribal people in Australia, it is not normal to thank the person who made the compliment because the compliment is seen as an unsolicited statement of fact. It is normal to smile, however, to show one's pleasure. Hofstede (1991), suggests that the culture is the collective programming of the mind which distinguishes the members of one category of people from another. This is reflected in the speech of each category of people, and salutations form key cues to the acknowledgement of group membership, and non-membership. More and more people recognize that living as global citizens means not only being able to communicate in other languages, but also to deeply understand the similarities and the differences between language cultures, and how central culture is to language; without culture, language cannot exist, or vice versa.

Sociolinguistic awareness means not just knowing the words and grammar of the new language, but also the cultural and social overlays over the words. "Old" in many a culture is a respectful word; an old man is someone to be respected. However, in English, it is a neutral statement of fact, and can even be understood negatively, leading to ambiguity and misunderstanding even among English speakers, such as when a (British) student discussed with her (non-British) teacher an item of news where a 100-year old man took part in a 100-meter race. She said: "He is such an old man. Could he even run anymore?" Her teacher suggested it would have been better to refer to the gentleman as "elderly" or a "senior citizen", rather "old", focusing on the concept of politeness, whereas the student was merely making a statement of fact. An understanding of the role of the "title or Name" as forms of address is particularly important in inter-cultural communication. In English these are often included in salutations, e.g. Good Morning, Professor Jones. The address form can be a title of some kind, or the person's name or both (Björk \& Räisänen, 2003; Blake, 1996; 
Downes \& Downes, 1998). In some cultures, such as Malayo-Polynesian cultures and Japanese culture, a salutation must always contain an address form unless the interlocutors are very close, and where possible avoidance of the person's name, at least the personal name. In formal, upper class British society, often either only the "title or the surname" can be used as a salutation, or both together, without an accompanying phrase such as "good morning". Even a simple nod (a slight bow of the head) is sufficient without any oral acknowledgement. Learning cultural norms plays an irreplaceable role in improving cross-cultural communication and the avoidance of cultural "faux-pas". We all at first assume our own norms are universal and discover, sometimes safely, sometimes with unwanted consequences, that they are not. Learners of English need to study English salutations and address forms and how their use significantly shapes interaction (Lundahl, 2009; Melin \& Lange, 2000; Fasold, 2000; Trudgill, 1999).

\section{Materials and Methods}

The research conducted to define changes in uses of salutations in British English specifically on public and private sectors and how people handle the changes, in both formal and informal situations. The data collected from YouTube videos text, in both written and spoken contexts as well as academic and social. This research attempted to describe the above phenomenon based on the facts that occur at the current time and therefore, the authors used descriptive techniques. However, the condition is undergoing changes in both academic and social contexts. Address forms are influenced by social mores and evolution in society. The philosophy of privacy, the individual and social-liberalism is strong in English-speaking countries and beyond, also being found in various ways in Northern Europe in general, as well as elsewhere. One needs to pay attention to the individual's privacy and self-determination, to value the individual's values, respect the choices of the individual, with an accompanying concept of social equality and the liberal belief that all have an equal right to advancement in society, wealth and education, and all this to make society better for all (Menaka \& Sankar, 2019; Astawa et al., 2017).

The Rights of Man, Woman and Child to freedom of speech, to education, to express politics and religion as they see fit, are at least in words sacrosanct. This means that equality despite background (gender, politics, economics, religion, age, etc.) is at least given lip-service, even if in reality such freedom of equality is still a dream for many. However, the attitude towards manners and personal responsibility to society are influenced, and this is reflected in address forms, and the tendency for formal forms of address to become neutralized on the one hand, or to disappear on the other. In this British society is no different from many other "western" societies (Cruttenden, 2014; Davies, 2012; Lagerholm, 2008). This can be very different from other philosophies, such as those based on Buddhism, Islam, Communism or Confucianism. One of the tenets of this latter is: "What you do not want done to yourself, do not do unto others"; found in Christianity as one of Christ's sayings "Do unto others as you would have them do unto you." Confucius also said "The injuries done to you by an enemy should be returned with a combination of love and justice", similar perhaps in spirit to Christ's sayings "turn the other cheek" and "love your enemies, bless them that curse you, do good to them that hate you, and pray for them which despitefully use you, and persecute you". Christianity developed in a Mediterranean world of Empire, great injustice, of extended families, slavery, and international trade protected by the Empire, sometimes excessive taxation and corruption, and represented a way for the Believers to be happy with their lot, even in adversity, because in the Afterlife there would be Heaven. This philosophy was overlaid on pre-Christian societies, leading to the system of address forms that circled around the three-way categorization of Address forms between a) Friends and acquaintances of a lower or equal status in non-elite groups, b) Friends and acquaintances in elite groups, and c) Official category or position denotation.

One could postulate that the reduction of family sizes in England is common with many countries and could also lead to a reduction in kinterms. In the 1996 census in the UK, families with one child were $42 \%$ of the total number of families, those with 2 children were $41 \%$ and those with three or more children were $17 \%$. This had not changed much in the 2016 census. One-child families were at $45 \%$, two-child families at $40 \%$ and families with 3 or more children at $15 \%$. The figures suggest that family sizes are getting smaller, with $83 \%$ of families having only 1 or 2 children in $1996,85 \%$ in 2016 . The number of couples living together without children, however, came out at $62 \%$ in 2016 , as opposed to only $44 \%$ in 1996 . The families are not only decreasing and size, there are fewer kin, one could postulate that kin terms could diminish in number; however, at present, language use does not bear this out. The reduction and change in English kin-terms happened some centuries before the Industrial Revolution, and their use in stories, among families with extended kin and the like maintain their regular use. (https://www.ons.gov.uk/peoplepopulationandcommunity/birthsdeathsandmarriages/families/bulletins/familiesandho useholds/2016)

Hassan, A., Mitchell, R., \& Buriro, H. A. (2020). Changes in uses of salutations in British English. International Research Journal of Management, IT and Social Sciences, 7(1), 197-204. https://doi.org/10.21744/irjmis.v7n1.840 
Salutations and forms of address in English

In English, titles and/or names often form part of the salutation, but are not an obligatory part. The norms of the use of names in salutation are common to all English speaking peoples in the "core" countries (e.g. Britain, Ireland, the US, Canada, Australia, New Zealand, South Africa, the Channel Islands, the Isle of Man) and in some "non-core" counties, such as Jamaica, Barbados, etc. As it is the use of names that shows the main relative social status of the interlocutors, we outline the core "rules" first.

\section{Friends and acquaintances of a lower or equal status in non-elite groups}

The personal name is used, or a "diminutive" form of this. The personal name is the name that the person prefers to be used in reference to him/her; alternatively, it can be a name that others prefer to use when addressing or referring to that person. It is common for coworkers, neighbours and other acquaintance friends not to even know each other's family name, and in the most informal of contexts, a nickname can be used.

\section{Friends and acquaintances in elite groups}

In old-fashioned or very conservative élite society, the surname, the "noble" name or the title was used. The "noble" name was either the name of the country or county, in the case of landed nobility or royalty, or the name chosen by the noble person as the name representing their nobility. In such cases, the first name may well be unknown to acquaintances. Over time, however, this custom is loosening, and may never have been followed except by the most "snobbish". In less formal contexts, the use of the personal name, or a "diminutive", or a nickname is much the same as in non-elite groups.

\section{Official category or position denotation}

In hierarchical groups such as the military and the Church, the title is most commonly used, and not the name, i.e. Father, Captain, Private; this is because the title establishes the addressee's position in the hierarchy but not the addressor's. The surname can be used with the title, particularly in cases of ambiguity, such as when there are a group of Captains. This use of "title" plus optional use of surname also appears when the official function of a person is in focus, e.g. Postman, Engineer, Shop Keeper, particularly when the person speaking either does not know the name, or wants to keep a degree of official distance.

Belonging in this category are words that denote the "biological" position of the addressee in society, such as boy, girl, man, woman, young man and old lady. These words are only used when the name and/or social position is unknown or in hierarchical contexts where the person is either treated as not having a name (e.g. a slave, a low-level servant), or where there is a distinct difference in age, such as older people using boy or girl to refer to much younger people, or the younger using terms such as old man or old lady for those much older, often in endearment. This of course can create problems, when the addressee feels offended by the use, such as when the dean of a British university once introduced a new American lecturer by addressing her as "girl", which embarrassed her greatly. The word "girl" can imply social and intellectual inferiority in both the US and Britain, and using "girl" to refer to a highly educated and articulate adult female is quite offensive.

A special case of "category" address form is "you" when used as a form of address. It is direct, in general impolite, and is used to identify the addressee when the speaker either does not know the addressee's name or rank, or because in the haste of the communication, uses "you" with a pointing finger because it is quick and direct. In all groups, the personal and family name are rarely used together in direct address; this use can happen when either the first or family name are ambiguous within the group, or in public address when the person is being called, such as in a doctor's waiting room; however, perhaps most commonly, the joint use is used when the person addressed is in some kind of trouble. The distinction overlaps with that of formal versus informal address, where the use or non-use of titles comes into play.

\section{Terms of Salutations}

Terms of salutation differ according to social status and class, as well as profession. These differ in formality rather than the vague hierarchical distinction of "elite, non-elite and official denotation", and the one form of address can appear in more than one category (e.g. "love" and "dear" below). They include: 
a) Terms of endearment, such as "honey", "dear", "love”, “deary”, “darling”, "pumpkin”, "baby";

b) Terms of friendship and/or equality, such as "mate", "my friend", "love";

c) Terms of respect, such as "Sir", "Madam/Ma'am", "Miss";

d) Social class, profession or category, such as "Father", "Brother", "Captain", "Lady/My Lady", "My Lord", "Reverend", "Professor", "Duke", "Your Majesty", "Boy”, "Girlie”, "Woman”;

e) Kinship terms, such as "Dad”, "Mum”, “Aunty”, Grandma”, "Nanna”, "Pop”, "Sis”, "Father”, "Sister".

Misuse of Terms of Address leads to misunderstanding, particularly Terms of Endearment and Terms of Respect. Terms of endearment are only used with those that we are very close to, family, boyfriend/girlfriend, wife, mother, father, child, grandparents, very close friends and the like. Terms like "honey" and "darling" can only be used with that special person, girlfriend, boyfriend, husband or wife, or parents, grandparents, uncles or aunts (etc.) with children, or more rarely teachers with children. Others, such as "dear", "deary" and "love", can also be used with and by other close people; however, great care must be used. Using such terms those are not in these close categories are very inappropriate. Misusing Terms of Respect can be disrespectful or even condescending. Such is a misuse of "Dear" by non-native English speakers outside the realm of address in letters and the like as a term of respect; it is never used as such except in very clear contexts, and when misused, can imply a loving relationship that approaches the expression of love for someone. If used in a formal setting, it is normally prefixed by "my" along with other address forms that show the ceremoniousness of the usage, i.e. "my dear Professor Jones", "my dear fellow".

\section{Terms of friendship and/or equality}

These terms, such as "mate" and "love/lovey"”, are used between relative equals, such as siblings, friends, classmates, workmates, and so on. However, "mate", "love/lovey" and the like or considered "lower class" terms, and so tend not to be used in more formal contexts in the UK.

\section{Kinship terms}

Kinship terms are used to refer and fix ones relatives in a kinship system. As kinship systems vary in the world, so does the use of kinship terms. As this forms a major part of anthropological and sociolinguistic studies, the literature on kinship terminology is considerable. Kinship systems are a characteristic of all language cultures due to their key importance in social organization - and the terms are not restricted to the kin, but also widely used in a variety of social organizational systems, such as "Father" for priest, "Brother" for a monk, "Sister" for a nun, "Uncle" to refer to any older man not part of the family, and so on. Terms such as fraternity (derived from Latin frater 'brother'), brotherhood, patriarchal (derived from Latin pater 'father') and so on show how central the metaphors of kinship roles and obligations can be in society. While blood ("genetic") relationships form the core of any kinship system, various other societal factors are taken into consideration, such as sex, age, generation, marriage, social position/hierarchy, reference versus address forms, diminutives, etc. In English, only certain kinship terms are commonly used in address with those kin with whom it is 'not done' to use their name. These are first and foremost the parents, then the grandparents and parent's siblings. In such cases, merely Dad (for younger children "Daddy") and Mum (younger children "Mummy") are used without any name reference; "Father" and "Mother" can be used, how this is considered very formal. In very high old-fashioned formal during the late Victorian and the following Edwardian years, the Latin Pater 'Father' and Mater 'Mother' were at times used by the very "snob".

For the grandparents, uncles and aunties (and sometimes the in-laws of the same generations), either the kinship term on its own is used (e.g. Grandad, Grandpa, Granfer, Grandfather; Grandma, Grandmum, Nana, Nan/Nannie, Grandmother; Uncle; Aunt, Auntie/Aunty), or the kin term plus the first name (e.g. Uncle John, Auntie Jane). In the case of the grandparents, the kin term plus family name in formal contexts (Grandad Mitchell, Grandfather Mitchell), or the kin term plus first name or diminutive in more friendly, loving contexts (Grandad William, Grandfer Bill). On the other hand, some families allow the children to use the first name even with the parents, grandparents, uncles and aunts and in-laws of those generations. This is normally a choice of the parents and/or other people of their generation or the previous generation. When used in reference to priests, monks and the like, the kin term, e.g. father, brother, sister and mother, or alternatively the kin term plus the first name or family name are used : father, father John, Father Peters (for a priest called John Peters).

Hassan, A., Mitchell, R., \& Buriro, H. A. (2020). Changes in uses of salutations in British English. International Research Journal of Management, IT and Social Sciences, 7(1), 197-204. https://doi.org/10.21744/irjmis.v7n1.840 
The universality of forms of salutations in English-speaking countries

In all English-speaking countries, address forms and salutations have experienced some evolution. For some decades now, regardless of one's social status or occupation or age, the first name or diminutive or nickname can be used to address the boss, older people, and as noted above, even parents and other kin of the previous generations. Few professions now demand a professional title as part of the address form and salutation, the ones retained being "Father", "Brother", "Mother (Superior)", "Sister", "Professor", "Doctor", "Reverend", "Pastor", "President"; "Queen”, "Your Grace", "Mister", "Madam/Ma'am", Miss", etc. - namely, those forms of address that denote a strict hierarchical position. For the bulk of English speakers, everyday formal address forms are terms such as Mr, Mrs, Miss and Miss, as well as "Ladies and Gentlemen", used to address mixed gathering in relatively formal contexts, be this at church, at meetings, in press conferences and etc. "Ladies" or "Gentlemen" of course may also be used separately, as in "Good morning, Ladies!"; however, the singular forms are never found, except in the formal address formula "My Lady", the female equivalent of "My Lord".

For some decades now in Britain and other Anglo-Celtic countries, overt expression of "power" has become less important in address forms, with a strong tendency to a "democratisation" of society which does not necessarily coincide with an actual leveling of society. Rather, the overt class distinctions inherent in some address forms came into disfavor as the "lower classes" gained more prominence, and often wealth over time. Terms such as "Sir" and "Madam" in everyday use are almost restricted to shop keepers/assistants, hotel receptionists and the like when addressing customers and guests in more formal circumstances, or otherwise by servants to their higher class bosses. As Brown and Gilman YEAR point out, except in strongly hierarchical contexts, "power" in daily communication has been to quite a large extent replaced by apparent "equality" and "intimacy".

While Doctor and Professor, Rector and Dean, King, Queen, Duke and Duchess, Earl, Count, Judge, Chef and similar high-level profession terms are commonly used in address, even when the name is known, most such professional terms such as "Teacher", "Engineer", "Cleaner" never seemed to have been established in Anglo-Saxon cultures, even though they were and are still used at times, such as when addressing the "Teacher", "Postman", "Milkman", "Plumber" or "Shopkeeper", e.g. "Excuse, Milkman, could you leave us two bottles of cream tomorrow, thank you?". As stated earlier, this generally happens when the speaker does not know the name of the professional. These terms can also relatively recently developed diminutive forms, particularly "Teach", "Postie" or "Shoppie", though not normally *Milkie or *Plumbie; these latter resemble other words in the language too much to be comfortably used. Australian English, understood by many British through Neighbours and similar Australian soap operas, does have "Milko" and "Plummo" as diminutives of "milkman" and "plumber"; however, these are probably never used in Britain, except when jokingly copying Australian speech. When the person's name is known, however, it is considered good form to use that person's name in address, and not that polite to use the profession term. Instead of "teacher", however, "Sir" and "Miss" are commonly used, the latter regardless of marital state. If the students and teacher are very familiar, the teacher's name or even nickname can be used by the students as long as the teacher or the institution allows this.

\section{The family name}

The English, as with all other English speaking peoples, usually do not use the surname without an accompanying title, except in certain professions, hierarchical or social circles, such as the military, upper class schools, and so on, as noted already.

\section{Results and Discussions}

The influence of non-English speakers on salutations in Modern British society is not easy to quantify. While other English speakers tend to use their local salutations, at least with each other, they also tend to use the British salutations when in the UK. Salutations such as "G'day" from Australia are seen as to "colonial", while "how are you doing?", felt to be American, is actually British in being common to the states and the UK. Regional salutations are used by the mainstream but with overt awareness that they are not mainstream, and so often either in jest, or in acting, or sometimes as a mark of respect is to make the addressee feel at home or at times as mockery. The stage Irish "Top of the morning to you" comes to mind. Other English speakers, the British use the salutations common to all English speaking peoples and at times regional British forms. Non-English speakers, this is tempered by how well the other 
person speaks English, and how much the British person knows of the other's ways. Those are aware of the other's culture, at times use (or at least attempt to use) the other's address forms, such as using "san" after Japanese names, or "Mam'selle" with young French women. In general, the appropriate English salutation is used according to the position of the person within British society. However, in offensive address, a random first name, such as "Mohammad!" or "Fritz!", or nickname, such as "Frenchie!" or "Frog!" can be used in addressing or referring to that person, as can be done in offensive address to British people, such as "Mick!" in addressing Northern Irish. Such address is considered highly offensive, even if used in jest.

As many an academic in Britain is of non-British background, salutations in academia come in various forms, reflecting on the whole unawareness of the "native" British system, or, even when the user is aware, a preference to use what he/she considers as more respectful, or has misunderstood as being more respectful, such as using the first name along with the surname when preceded by a title in direct address rather than the more normal usage of this indirect reference. How much influence this is having on address forms in academia and beyond in Britain is as yet unmeasurable. The examples found all seem to include at least one interlocutor who has not yet learnt the ways of British academia. Outside of academia, non-English address forms are known, but have been fitted into the existing system, as with "Rabbi", "Imam" and similar terms, treated on a par with "Father", Other address forms, such as "Hajji", are too specific to a cultural milieu to be used in general discourse outside that milieu. While such terms are known and used in Britain, like their equivalent terms in traditional British society, they fit into the hierarchy of their own system.

\section{Conclusion}

Language is the mirror and the vehicle of society, and has an integral relationship to culture, in that language truly reflects all aspects of the society, and the society can only exist and be passed on through its language. As societies change, so does how its language expresses the society. As an indispensable unit of language, salutations are barometer-like in measuring how people think of others and their inter-personal relationships. Differences in how address forms are used therefore exist between all cultures, Eastern types, Western types, the South, the North, between peoples as geographically close to each other as the English, French and Germans, let alone between those on opposite sides of the world, and let alone people of different generations or social classes within the one culture. It is important to have a deeper understanding of the culture of both sides in any interaction, their differences, similarities and characteristics.

A finding from a general perusal of data such as informal and formal contexts, use in chat rooms, academic papers and so on, is that some polite salutations seem to be becoming more generalized, i.e. seem to be becoming more informal in spoken English, while others seem to be disappearing from use. This appears to be a long term process, assisted by the democratization of society, perhaps led by the US, Canada, Australia and other former colonies. On the other hand, non-English forms of address do not yet seem to have made any direct impact.

\section{Conflict of interest statement}

The authors declared that they have no competing interests.

\section{Statement of authorship}

The authors have a responsibility for the conception and design of the study. The authors have approved the final article.

\section{Acknowledgments}

We grateful to two anonymous reviewers for their valuable comments on the earlier version of this paper. 


\section{References}

Abercrombie, D. (1979). The accents of standard English in Scotland. Languages of Scotland, 68-84.

Astawa, I. N., Handayani, N. D., Mantra, I. B. N., \& Wardana, I. K. (2017). Writing English language test items as a learning device: a principle of habit formation rules. International Journal of Social Sciences and Humanities, 1(3), 135-144. https://doi.org/10.29332/ijssh.v1n3.67

Baugh, A. C., \& Cable, T. (1991). A History of the English Language (3'd Ed.). London and New York: Routledge.

Björk, L., \& Räisänen, C. (2003). Academic writing: a university course course. Studentlitteratur.

Blake, N. (1996). A history of the English language. Macmillan International Higher Education.

Cruttenden, A. (2014). Gimson's pronunciation of English. Routledge.

Davies, P. (2012). 'Me','me','me': The use of the first person in academic writing and some reflections on subjective analyses of personal experiences. Sociology, 46(4), 744-752. https://doi.org/10.1177\%2F0038038512437897

Downes, W., \& Downes, S. F. W. (1998). Language and society. Cambridge University Press.

Fasold, R. (2000). The Sociolinguistim of Language.

Fasold, R. W. (2000). Ebonic need not be English. AAA: Arbeiten aus Anglistik und Amerikanistik, 149-160.

Hofstede, G. (1991). Empirical models of cultural differences.

Lagerholm, P. (2008). Stilistik. Studentlitteratur.

Lundahl, B. (2009). Engelsk språkdidaktik: texter, kommunikation, språkutveckling.

Melin, L., \& Lange, S. (2000). Att analysera text: stilanalys med exempel. Studentlitteratur.

Menaka, G., \& Sankar, G. (2019). The language learning assessment using technology for the second language learners. International Journal of Linguistics, Literature and Culture, 5(4), 1-6. https://doi.org/10.21744/ijllc.v5n4.674

Trudgill, P. (1999). The Dialects of England. Blackwell. 